\title{
STUDIES
}

\section{INFORMAL SEARCH AND JOB OPPORTUNITIES AMONG SECONDARY-SCHOOL LEAVERS IN HUNGARY*}

\author{
Tamás BARTUS \\ Department of Sociology and Social Policy, Budapest University of Economic Sciences and PA \\ Budapest, Fővám tér 8. H-1093; e-mail: tamas.bartus@bkae.hu
}

\begin{abstract}
This paper addresses two questions: (1) Do informal job searchers find good jobs in Hungary? (2) Do social resources theory and the theory of employee referrals explain the conditions under which informal job searchers find good jobs? The questions are examined using a rather unique dataset which was collected among people who completed secondary vocational education in 1998. It is found that the use of informal methods in itself rarely promotes one's chances of finding a good job. Rather, good jobs can be accessed through either high status contacts or employee referrals. These findings are consistent with both social resources theory and the theory of employee referrals.
\end{abstract}

Keywords: social networks, labor market, social resources theory

\section{INTRODUCTION}

This paper examines whether friends and relatives help job seekers to get a good job in Hungary. Using the rather general idea of path-dependence (David 1985; Arthur 1988; North 1990), it has been argued that personal contacts become even more important during the transition from communism to capitalism (Sik 1994; see also Czakó and Sík 1994, 1995). Although there is evidence documenting the extensive use of personal contacts in recruitment (Csegény et al. 1996; Laki 1997; Laki [unpublished]), there are no studies examining the effects of personal contacts on labor market outcomes (for a study before the transition, see Böröcz and Southworth 1998).

Our aim is to answer two research questions. The first question is whether job searchers are more likely to find good jobs with the help of informal intermediaries

* This paper summarizes some of the results contained in my PhD dissertation Social Capital and Earnings Inequalities. The Role of Informal Job Search in Hungary. The thesis work was supervised by Jules Peschar, Tom Snijders (both associated with the University of Groningen) and Beate Völker (University of Utrecht) whose support is acknowledged. Helpful comments were received from Peter M. Marsden, Róbert Tardos, Endre Sík and János Köllö. The data collection was financially supported by the Department of Sociology at the University of Groningen. 
than through other job-finding methods. Previous research on contact effects has shown that the use of informal search in itself rarely leads to good jobs. There are two theories that can account for the conditions under which personal contacts help job searchers to get good jobs (see Section 2). Social resources theory, a follow-up to the famous strength of weak ties hypothesis, argues that returns to informal methods depend on the status of the contact person. Another theory, which wll be labeled the theory of employee referrals, claims that good jobs can be accessed with the help of employee referrals. Thus, we ask a second research question: is it true that informal job search leads to good job only if the contact person is either a high-status person or an employee where the job opening is? Raising the second question is equivalent to the aim of testing social resources theory and the theory of employee referrals.

The paper is organized as follows. Section 2 offers a review of the relevant theories, namely the theory of employee referrals and social resources theory, that turned out to be useful in describing the effects of informal job search on various labor market outcomes. The remainder of the paper is devoted to the description of the effects of informal job search. Section 3 describes the data and the methods that will be used in the empirical analyses. The results of the empirical analyses are reported in Section 4. Section 5 draws the conclusions.

\section{THEORETICAL BACKGROUND}

In the past decades, a considerable amount of research has been examining the question whether informal methods lead to relatively good jobs. For detailed overviews, the reader should consult Preisendörfer and Voss (1988), Flap and Tazelaar (1989), Granovetter (1995), Lin (1999), Marsden and Gorman (2001), and Bartus (2001). This line of research unambiguously showed that personal contacts in themselves rarely lead to better jobs than direct and formal search methods. ${ }^{1}$ Several theories were proposed to specify the conditions under which personal contacts lead to better jobs. The most often used theories are the theory of employee referrals, the strength of weak ties hypothesis and social resources theory.

\section{The Strength of Weak Ties Hypothesis and Social Resources Theory}

Many sociologists would agree that the study of the relationship between contacts and careers originates in the works of Granovetter $(1973,1974)$. His famous strength of weak ties hypothesis is motivated by the finding that job seekers often receive job information as a by-product of social interactions which are often initiated by the contact persons (Granovetter 1974). Granovetter argued that the transmission of job information should be seen as a diffusion process. If the assumption of diffusion

1 Direct search methods are those that do not involve any intermediary between the job searcher and the employer. Typical examples are want-ads and the job searchers' enquiries at firms. Formal search methods are those methods that involve an institutionalized intermediary between the job searcher and the employer. Formal search methods involve employment agencies, newspaper ads, and the Internet. 
process is correct then weak rather than strong ties are useful for job seekers to get a good job. However, subsequent empirical research failed to support this hypothesis unambiguously. When the study is restricted to high status jobs (or when an interaction term between status of job and tie strength is introduced into the analysis), it turns out that weak rather than strong ties lead to jobs with higher status (Wegener 1991) or earnings (Bridges and Villemez 1986; Ericksen and Yancey 1980; Boxman et al. 1991). The advantages of weak ties were also established among employees with short job tenure (Bridges and Villemez 1986) and among males (Beggs and Hurlbert 1997). However, studies examining a representative population of employees did not replicate Granovetter's famous result (Bridges and Villemez 1986; Marsden and Hurlbert 1988; Greenwell et al. 1997). It was also pointed out that the failure to replicate Granovetter's hypothesis might be due to the fact that the contact person is not necessarily the ultimate helper (Bian 1997; Bian and Ang 1997).

Social resources theory can be viewed as a logical extension of the strength of weak ties hypothesis so that the limited empirical support for the latter theory can be overcome. Using the observation that the success of instrumental action depends on the status of the person mobilized (Lin et al. 1978), it was suggested that returns to informal methods depends not on tie strength but on the status of the contact person. Weak ties have only an indirect effect: they increase the chances of accessing high status contacts.

The hypothesis that the status of the contact person promotes success goes back to the idea that labor market information and influence is unevenly distributed: the higher the status of a person the more knowledge and influence this person has. Therefore, upward mobility of people using personal contacts depends on the status of the contact person. The mobilization of high status contacts depends on the use of weak ties, on the one hand, and the status of origin, on the other. These relationships are understood with the help of the homophily principle (Laumann 1966; Verbrugge 1977; Fischer 1982; Campbell et al 1986; Marsden 1988): social interactions tend to take place among similar actors and thereby dissimilar - in our case, high-status - actors can be reached through weak ties. For this reason, high-status people have an easy access to other high-status people (strength-of-position hypothesis). Besides, access to high-status people is facilitated by the use of weak ties. Since the emergence of strong ties requires repeated interactions, and similar people engage in frequent interactions, strong ties evolve among similar actors. By the same logic, the ties between dissimilar actors remain weak. Thus, weak ties are more apt to reach dissimilar people (strength of ties hypothesis). Note that the use of weak ties is especially important in low-status positions. Due to the homophily principle the status range of personal networks is restricted. High-status people can easily find other high-status people in their personal network. On the contrary, in low social positions, access to high-status people requires weak ties that can help in transcending the restriction of personal networks. To summarize, persons of low social origin have to use weak ties in order to contact a high-status person, while high-status persons can reach high contacts through strong ties (the interaction hypothesis).

There is considerable empirical support for the hypothesis that contact status has a positive impact on attained status, and the effect of tie strength, if any, can be explained 
away in terms of contact status. Most of the confirming evidence comes from studies where status attainment models were estimated (Ensel 1979; Lin et al. 1981; Lin 1982; Flap and De Graaf 1986; De Graaf and Flap 1988; Boxman 1992; Bian and Ang 1997; Bian 1997; Lai et al. 1998; Völker and Flap 1999; for disconfirming evidence, see Requena 1991). The results lead to the same conclusions when other measures of background are added to education (introduction of age or work experience, and sex) and also the tie strength between the contact and the job seeker is controlled for (Marsden and Hurlbert 1988; Wegener 1991; Bian 1997). Unfortunately, these results are not replicated when the effect of contact status on income is studied. The effect of contact status becomes either insignificant (De Graaf and Flap 1988; Marsden and Hurlbert 1988) or reversed (Requena 1991).

\section{The Theory of Employee Referrals ${ }^{2}$}

The theory of employee referrals elaborates upon a special case of getting a job informally. First, as the concept of employee referrals suggest, these are the employees who bring vacancies and persons together. Getting a job through a social friend of the employer is not an employee referral. Second, these are the employers who ask the workers to bring new applicants to the firm. Referrals are a systematic or institutionalized means of filling vacancies, without using other labor market intermediaries. Thus, finding out about a job through a person who has just seen an advertisement or who works in an employment agency is not a referral. The questions of why employees play such a central role and why the theory neglects other forms of contacts are considered after elaborating on the incentives of relying on referrals.

The basic idea of the theory is simple: employers perceive referrals as a cheap way of getting good workers. In other words, employee referrals are assumed to reduce various labor costs. In the literature, we can find five reasons why this might be so (Rees 1966; Rees and Shultz 1970; Fernandez et al. 2000).

First, referrals are assumed to lower the costs of recruiting new workers. This is not surprising since employers do not need to spend resources in order to encounter applicants. Note that the assumption behind this argument is that the only cost of recruitment is the costs associated with using agencies and placing advertisements.

Second, referrals reduce the costs of screening. Screening costs both time and effort since the individual characteristics of applicants must be inspected. This time and effort become lower when applicants form a homogeneous group. If the homophily principle holds, employees and applicants are similar with respect to human capital characteristics, thus employee referrals are likely to produce such a

2 The research into personal contacts in labor markets was motivated by the insight that there are important uncertainties in labor markets, and uncertainties can be overcome with the help of informal methods (Rees 1966). Based on the assumption that the use of personal connections to match persons to positions depends mainly on the behavior of employers, this insight was further elaborated and a coherent theory emerged. The theoretical ideas were often used in empirical studies of employers' recruitment practices, mainly carried out in US and British settings. Since the concept of employee referrals plays a key role here, I label this theory the theory of employee referrals.

Review of Sociology 9 (2003) 
homogeneous pool. Employee referrals save hiring costs not only because applicants are homogeneous but also because they are similar to the current employees. If the similarity between employees and applicants were perfect, the known characteristics of the employee would inform employers about the unknown characteristics of the applicant. In this extreme case, the first applicant could be hired without any screening effort, thus selection costs would be zero.

Third, referrals might lower the costs of training. Again, the argument rests on the assumption that applicants and current employees are similar with respect to human capital characteristics. First, applicants similar to employees have a better understanding of the job to be done. Second, many skills can be acquired through learning from the experience of others. The similarity between applicants and employees might create a friendly environment which enables the transmission of experiences of employees. Therefore, the similarity between applicants and employees increases the probability that newcomers will acquire firm-specific skills and values (Manwaring 1984).

Fourth, informal recruitment might reduce monitoring costs, i.e. the costs of supervising workers, or alternatively, it might increase the commitment and discipline of newcomers. The opportunistic behavior of newcomers might harm the reputation of the person who gave the referral. Employees are interested in building a reputation, especially those working in firms where good jobs are filled through internal promotion. Therefore employees are interested in referring only good and reliable workers. Additionally, employees are interested in controlling the behavior of the referred workers so that their reputation is not destroyed by the behavior of the newcomer. The reputation protection of workers thus maintains the reliability of the workers. Since the employer achieves this outcome without any monitoring efforts, referrals can substitute for costly monitoring.

Finally, employee referrals might reduce turnover. Turnover is costly since new workers should be hired and trained, and separation may involve direct administration costs. There are two reasons why referred employees will stay longer with the firm. First, employee referrals enable job seekers to have a look inside the firm, a unique opportunity which is not present when job seekers use formal intermediaries. Job seekers using referrals will learn about job and firm characteristics (fairness and attitudes of supervisors, colleagues, working conditions) (Rees 1966; Rees and Shultz 1970) and about the negative aspects of the job (Decker and Cornelius 1979; Wanous 1980). Second, the referrals might help newcomers to fit in with colleagues (Coverdill 1998, Fernandez et al. 2000).

The theory also suggests that labor costs are saved only if the firm pays high wages. First, hiring through workers reduce recruitment costs only if the firm is able to attract workers. Filling a vacancy through personal methods is likely to take longer than to find an applicant through formal channels (Kugler 1997). Since empty vacancies have opportunity costs, informal methods are not cheap if it takes a long time to fill a vacancy. Obviously, high wages attract a large number of applicants, thus vacancies can be filled quickly. However, high wages also create incentives to cut search costs, thus high-wage firms are likely to use employee referrals. Costly recruitment methods like agencies or advertisements are used by employers who pay low wages or who pick 
up inexperienced applicants and train them later (training is salient for large firms where specialization is possible, Ullman 1968). Second, referrals save monitoring costs only if employers think of their workers as good and honest (Montgomery 1991; Kugler 1997). Monitoring costs are saved due to the similarity or friendship between the current employee and the newcomer. However, similarity is valuable only if the current workforce has good quality and it can be trusted. Additionally, friendship among the employees can work against the interests of employers (Fernandez et al. 2000). Therefore, employers avoid the use of referrals when they wish to upgrade their workforce or they have bad experiences with cliques (Rees 1966; Ullman 1968; Manwaring and Wood 1984). As various efficiency wage models (Akerlof 1982; Shapiro and Stiglitz 1984; Yellen 1984) suggest, firm-internal promotion or the payment of high wages promotes the honesty of workforce. Thus, in high-wage jobs there are more reasons to trust the current workforce and to expect employees to control the behavior of newcomers.

To conclude, employers find the use of employee referrals cheap when they pay high wages. This is so because two components of labor costs - recruitment costs and monitoring costs - are low when the wages paid are high. Therefore, mainly employers paying high wages will rely on referrals. From the point of view of job seekers, good jobs are accessed through employee referrals.

Support for the theory of employee referrals comes mainly from studies carried out in the US. The main concern of employers is the quality rather than the number of applicants (Neckerman and Kirschenman 1991). Referrals produce good quality applicants (Williams et al. 1993), or at least hiring managers hold this belief (Mencken and Winfield 1998). Studies using industry-level or firm-level data found a positive relationship between the proportion of employees hired through employee referrals and wages paid (Kugler 1997; Holzer 1987). The importance of referrals is also documented in ethnographic research: workers believe that obtaining a good job required either luck or the help of a friend who put in a good word with the employer (Wial 1991).

\section{DATA AND MEASUREMENT ${ }^{3}$}

\section{The Sample}

No existing Hungarian datasets contain detailed information on personal networks, job-search methods and labor market outcomes. For this reason, data collection was inevitable. Our target population consists of school leavers who completed secondary vocational education in 1998 and who live in large cities. This research design is consistent with most of the previous empirical studies which were carried out in urban labor markets. Besides, restricting the study to a particular population of job searchers

3 For details on the data collection not reported in this section, the reader is referred to Chapter 4 of Bartus (2001).

Review of Sociology 9 (2003) 
improves on previous empirical studies which usually use cross-sectional data of employees or a general population (for a notable exception, see Boxman 1992). There are several reasons for restricting the study to people completing secondary vocational education. Contrary to other special job-searcher populations (unemployed, job changers), the beginning of job search can easily be identified. Furthermore, school leavers are similar with respect to human capital (years of education, labor market experience, job tenure) and demographic characteristics (age, marital status). Thus, the control for these characteristics requires only few variables and thereby the chances of discovering statistically significant contact effects are relatively large. The disadvantages of this choice are that results cannot be generalized without precautions to other populations of job searchers. From a theoretical point of view, loss of generality would be a serious problem only if we were interested in testing the strength of the weak tie hypothesis. Recall that empirical tests suggest that this hypothesis holds for job searchers accessing high-status jobs. Our school leavers are with high probability people who will not compete for such high status jobs.

School leavers were sampled using a three-stage design. In the first state, the seven largest cities from each major statistical regions of Hungary were chosen. ${ }^{4}$ The second stage aimed at preparing the sampling frame. In the second stage, first an address list of secondary schools was prepared. Then interviewers visited the schools in order to collect the addresses of those pupils who completed their studies in 1998. Unfortunately, a considerable proportion of schools rejected cooperation, usually with reference to the Law on Data Security. In total, 75 schools provided the requested list of school leavers. In the third stage, a random sample of 750 pupils was drawn from the address list. Because a high proportion of non-response was expected, a supplementary list was also prepared. In case of non-response, interviewers were asked to select addresses from this supplementary list. The selection rule was that non-responses should be replaced with schoolmates (the order of schoolmates was also specified). Originally, the supplementary list included twice as many addresses as the main sample. Because of the high number of non-responses, it was necessary to place all addresses of the sampling frame on the supplementary list. The data were collected in face-to-face interviews using a structured questionnaire.

Sampled school leavers were approached twice: first during December 1998 February 1999, and then during September-October 1999. The second interview extends the observation window so that all sampled school leavers are likely to find job opportunities and thereby will report on the search method used and search outcomes. Without having the second wave, we could have run the risk of having not enough cases for data analyses examining the impact of search methods on labor market outcomes.

The sample for empirical analyses was constructed as follows. The first wave of the data collection resulted in 746 completed interviews. Out of the 746 observations, 49 were excluded from the sample, due to the absence of the identification number of the interviewed person in the sampling frame, or to the special demographic or labor market status of the individual (like having children, working in the military labor

4 The cities are Budapest, Debrecen, Győr, Miskolc, Pécs, Szeged and Székesfehérvár. 
force). Then missing information about the job search process and labor market outcomes were replaced using the second wave data. For instance, among those who were interviewed in the second wave $(\mathrm{N}=444)$, there are 103 people who did not hear about a job opportunity before the time of the first wave interview, or this information is missing. Out of the 697 school leavers, 620 individuals have heard about a job opportunity. These 620 individuals will constitute our sample.

\section{Definition of Variables}

Dependent variables. Analyses in this paper focus on the monetary value of job opportunities. The first measure of monetary value is net monthly earnings. This variable is constructed as follows. People who got the job they found were asked about their starting net monthly salary. People who did not get the job were asked the question "what would your net salary have been if you had gotten the job?" The survey items are open-ended questions. The income data are recorded in thousands of Hungarian Forint. In regression analyses, I will take the natural log of this variable since the distribution of earnings is skewed to the right.

This measure is limited to the extent that it does not indicate career opportunities and earnings in the future. To capture this long-term aspect in a way which uses information about job opportunities, I used two proxies: foreign property, and large firm. Foreign property is a dummy, identifying firms where there is some foreign property. Large firm is a dummy, identifying firms where the number of employees is above 50. The selection of these dummies was motivated by aggregated earnings figures taken from the publications of the Hungarian Central Statistical Office and regression results based on large-scale labor force surveys (Kertesi and Köllö 1997, 1998). The regression models for earnings will also include a white-collar job dummy identifying managerial, technical and clerical jobs.

Job finding methods are captured by three dummies. Based on the source of job information, previous research classified job-finding methods into three groups. The first group includes people who found an opportunity without the help of any intermediaries. In this group, we find people who visited firms, who have seen a "wanted" advertisement in the street, or those who already knew the employer. The second group includes people who heard about the job from a formal intermediary. I divided this group into two subgroups: advertisement and the employment service. The third group includes people who have found a job through personal intermediaries (contact person). Throughout the paper, the term informal source refers only to this group of people.

Contact characteristics are described with two dummies: high-status contact and employee referrals. High-status contacts are those who have professional, managerial, or technical occupations. This operational definition is consistent with Granovetter's (1974) study. The distinction between high and low-status occupations is closely related to educational requirements: filling high-status occupations typically requires either university diploma or technical education. Employee referrals identify those who work at the same workplace where the job opportunity is located. In the regression

Review of Sociology 9 (2003) 
analyses reported in the next section, these two dummies take the value zero if the job searcher found the job opportunity through formal channels or directly.

Besides these variables, the following control variables will be used. These variables are intended to capture human capital and regional differences. Education is a dummy, identifying people who obtained A-levels. Training is a dummy, identifying those who had at least one year of training outside school. Training outside school is presupposed to provide better abilities than training within the school. Gender is a dummy, identifying males. Finally, region identifies Budapest and the two western cities.

Table 1 shows means and standard deviations for the variables. Approximately 1 out of 4 job seekers found a job in a firm where there is foreign property. Similar is the proportion of those who found a job in a large firm or who found a white-collar job. An average job seeker found a job associated with about 27 thousand Hungarian Forints. The majority of school leavers got the job. The most popular job-finding methods are personal contacts (43.4 percent). Formal channels (employment services, advertisements) were used by 33.1 percent of people who found a job. The remaining 23.5 percent found a job through direct methods.

Table 1. Descriptive statistics for analyses $(\mathrm{N}=620)$

\begin{tabular}{|c|c|c|c|}
\hline Variables & $\mathrm{N}$ & Mean & $\mathrm{SD}$ \\
\hline Respondent got the job & 620 & 0.813 & 0.390 \\
\hline Net earnings opportunity (in 1000 HUF) & 552 & 26.962 & 10.368 \\
\hline Foreign property in firm & 577 & 0.241 & 0.428 \\
\hline Large firm: $\mathrm{N}$ of employees $>50$ & 595 & 0.267 & 0.443 \\
\hline White-collar job & 579 & 0.256 & 0.437 \\
\hline \multicolumn{4}{|l|}{ Source of job information: } \\
\hline - employment service & 601 & 0.086 & 0.281 \\
\hline - advertisement & 601 & 0.245 & 0.430 \\
\hline - direct methods & 601 & 0.235 & 0.424 \\
\hline - personal contacts & 601 & 0.434 & 0.496 \\
\hline - high-status contact & 584 & 0.116 & 0.321 \\
\hline - employee referral & 600 & 0.240 & 0.427 \\
\hline Education: R. obtained A-levels & 620 & 0.561 & 0.497 \\
\hline Training: at least 1 year outside school & 619 & 0.494 & 0.500 \\
\hline Gender: male & 620 & 0.589 & 0.492 \\
\hline Region: Budapest or western part & 620 & 0.584 & 0.493 \\
\hline
\end{tabular}

\section{EMPIRICAL ANALYSES}

This section describes the effects of job-finding methods and contact characteristics. First, using the sample of job seekers, we examine the distribution of job opportunities conditional on job-finding methods. Second, using again the sample of job seekers, we examine the chances of getting that job. Finally, we examine the effects of job-finding methods using a sample of employees. Note that in a typical getting-a-job study, the first two steps are missing. The first two steps test two possible stories about why people using contacts might get relatively good jobs. One story is 
that people using good contacts find opportunities that, on average, are better than opportunities found by other people. The second story is that people using contacts find opportunities with the same average quality as other people, but they are more able to pick up the best opportunity out of the heterogeneous pool.

\section{Characteristics of Job Opportunities}

Table 2 shows the distribution of foreign property, firm size, job and earnings opportunities across job-finding methods (panel A) and contact characteristics (panel B). Looking at panel A, we find substantial variation of the probability of finding a good job across job-finding methods. On average, 24.1 percent of young job seekers in our sample found a job opportunity in firms with foreign property (see Table 1). People who found the job through contacts are somewhat more successful $(27.2 \%)$. The best way of finding a job in firms with foreign property is reading or answering advertisements (33.8\%). Employment services and contacting employers without intermediaries are the worst job-finding methods: compared to the sample average, they halve the chances of finding a job in foreign property. The differences between agencies and informal methods, on the one hand, and agencies and direct methods, on the other, are large enough to reject the hypothesis of no differences across job-finding methods $\left(\chi^{2}\right.$ statistic with $\left.3 \mathrm{df}=21.76 ; \mathrm{p}<0.001\right)$.

Table 2. Distribution of job characteristics and earnings opportunities by job finding methods (Panel A) and contact characteristics (Panel B) (in percentages)

\begin{tabular}{|c|c|c|c|}
\hline Variables & $\begin{array}{l}\text { Foreign } \\
\text { property }\end{array}$ & $\begin{array}{l}\text { Large } \\
\text { firm }\end{array}$ & $\begin{array}{c}\text { Earnings } \\
\text { opportunity } \\
\text { (in } 1000 \mathrm{HUF} \text { ) }\end{array}$ \\
\hline \multicolumn{4}{|l|}{ Panel A Job-finding methods } \\
\hline Employment service & 12.5 & 26.0 & 23.93 \\
\hline Advertisement & 33.8 & 24.3 & 28.12 \\
\hline Direct methods & 12.6 & 19.9 & 25.78 \\
\hline Contact person & 27.2 & 32.0 & 27.34 \\
\hline Pearson $\chi^{2}$ test of independence $(\mathrm{df}=3)$ & 21.76 & 7.58 & \\
\hline ANOVA F $(3,547)$ & & & 2.53 \\
\hline p-value & 0.000 & 0.056 & 0.056 \\
\hline \multicolumn{4}{|l|}{ Panel B Characteristics of contact person } \\
\hline Low status, not employee & 12.9 & 14.3 & 26.23 \\
\hline High status, not employee & 21.9 & 29.4 & 30.93 \\
\hline Low-status employee & 27.4 & 36.5 & 26.32 \\
\hline High-status employee & 52.9 & 61.8 & 29.84 \\
\hline Pearson $\chi^{2}$ test of independence $(\mathrm{df}=3)$ & 19.48 & 24.72 & \\
\hline ANOVA F $(3,220)$ & & & 2.33 \\
\hline p-value & 0.000 & 0.000 & 0.075 \\
\hline
\end{tabular}


There is some weak evidence that personal contacts are the best means of finding a job in a large firm. Approximately one in four job seekers found a job opportunity in a large firm (26.7\%). Somewhat smaller figures characterize the chances among those who use formal intermediaries (26.0\% for agencies; $24.3 \%$ for ads). The chances of finding a vacancy in a large firm are larger by about 5 percent among people using informal intermediaries $(32.0 \%)$. Direct methods are the least appropriate to find a job in large firms (19.9\%). Note, however, that these differences are not significant at the conventional 5 percent level $\left(\chi^{2}\right.$ statistic with $\left.3 \mathrm{df}=7.58 ; \mathrm{p}=0.056\right)$.

An average job seeker found a job opportunity with a monthly net salary of about 26,900 Hungarian Forints (see Table 1). The results in panel A suggest that there is some variation in earnings opportunities across job finding methods. Employment services and direct methods lead to earnings opportunities below the average, while advertisements and contacts lead to jobs with above average earnings. However, the differences can also be attributed to sampling error (F-test of the hypothesis that group-specific means are equal: $\mathrm{F}=2.53 ; \mathrm{p}=0.056$ ).

Given the lack of statistical significance at the conventional 5 percent level, we cannot conclude that better opportunities can be found through personal contacts than through other methods. The simple tables suggest only that personal contacts and advertisements are better means of finding a job in a firm with foreign property than direct methods and employment services.

Social resources theory and the theory of employee referrals suggest that the lack of convincing evidence is due to the fact that the group of people finding a job through a contact person is heterogeneous with respect to the characteristics of the contact person. Panel B of Table 2 shows the distribution of our dependent variables across the categories of contact characteristics. The results clarly support the expectation that high status contacts and employee referrals provide information about better jobs than other contacts do, provided good means working in a large firm or in a firm with foreign property. The probability of finding a job in a firm with foreign property is the largest among high-status employee referrals. The smallest chance is associated with the use of low-status people who are not employees at the firm where the job opportunity is located. We find the same pattern if we examine the distribution of finding a job in a large firm. The earnings data show that high-status contacts help job searchers to find a job with relatively high earnings. However, these differences do not strongly support the hypothesis that the characteristics of the contact person matter ( $\mathrm{F}$ test of the hypothesis that group-specific means are equal is $2.33 ; \mathrm{p}=0.075$ ).

Our analyses proceed with regression analyses that control relevant human capital and regional characteristics. Table 3 shows the estimation results of two logistic regressions of foreign property and large firm on job-finding methods. The two equations are estimated separately. ${ }^{5}$ Three dummies capturing formal and direct

5 This simple strategy does not address the issue that foreign property and firm size are correlated. The correlation is due to the fact that foreign investors are likely to invest in large firms (because large firms are more visible), or to the fact that foreign investors set up large establishments. The ideal strategy would be to estimate the foreign property and large firm equations simultaneously. Additional analyses, not reported here, showed that simultaneous estimation does not affect the conclusions reported in this section. 
channels express sources of job information. In this way, we compare the effect of formal and direct job-finding methods to that of finding a job through contacts. If informal channels always lead to better jobs, regardless of contact characteristics, then the coefficients of all formal and direct channel variables must be negative.

Table 3. Logistic regressions of firm characteristics on job-finding methods

\begin{tabular}{lcccc}
\hline & \multicolumn{2}{c}{ Foreign property } & \multicolumn{2}{c}{ Large firm } \\
\hline Employment service & -0.946 & $(2.07)^{*}$ & -0.297 & $(0.86)$ \\
Advertisement & 0.343 & $(1.45)$ & -0.406 & $(1.73)$ \\
Direct methods & -0.881 & $(2.91)^{* *}$ & -0.648 & $(2.47)^{*}$ \\
Education: R. obtained A-levels & 0.048 & $(0.19)$ & 0.102 & $(0.48)$ \\
Training: at least 1 year outside school & -0.244 & $(1.01)$ & 0.070 & $(0.36)$ \\
Gender: male & 0.459 & $(2.04)^{*}$ & 0.202 & $(1.00)$ \\
Region: Budapest or western part & 0.733 & $(3.32)^{* * *}$ & 0.364 & $(1.75)$ \\
Constant & -1.667 & $(5.08)^{* * *}$ & -1.173 & $(3.97)^{* *}$ \\
& & & & \\
N of observations (N of clusters) & 575 & $(281)$ & 593 & $(283)$ \\
$\%$ reduction in log likelihood & 0.066 & & 0.019 & \\
$\chi^{2}$ statistics (df=7) & $39.23 * * *$ & & 13.28 & \\
\hline
\end{tabular}

Notes: Raw (or unstandardized) parameter estimates; figures in parentheses are absolute values of t ratios. Standard errors are adjusted for clustering on classes within schools.

$* \mathrm{p}<0.05 ; * * \mathrm{p}<0.01 ; * * * \mathrm{p}<0.001$; two-tailed tests

The effects of job-finding methods on finding a good job are mixed. In both equations, direct methods have the expected negative and statistically significant coefficients. This means that direct methods lead to worse jobs than informal methods. The formal channel variables have mainly the expected negative signs, but they are not significant with the exception of employment service concerning the foreign property equation. Thus, we cannot conclude that informal job-finding methods are better than all other job-finding methods.

It is also striking that education and training do not play an important role in finding a good job. Gender only affects the chances of finding a job in a firm with foreign property. People living in the western part of Hungary have more chances of finding good jobs. Regional differences are probably due to unequal distribution of foreign capital investment in Hungary (Fazekas and Köllö 1999). Hence, the regional dummy expresses structural opportunities to find firms with foreign property at all.

Table 4 shows estimation results of two logistic regressions of firm and job characteristics on contact characteristics. These regressions are appropriate to test social resources theory and the theory of employee referrals. Two dummies express the source of job information: high-status contact and employee referral. Note that these dummies take on the value zero when the job-finding method was other than personal contact. Thus, we compare "good" contacts to both "bad" contacts and to formal and direct methods of finding a job. 
Table 4. Logistic regressions of foreign property and firm size on contact characteristics

\begin{tabular}{|c|c|c|c|c|}
\hline \multirow[b]{2}{*}{ High-status contact } & \multicolumn{2}{|c|}{ Foreign property } & \multicolumn{2}{|c|}{ Large firm } \\
\hline & 0.618 & $(2.09)^{*}$ & 0.735 & $(2.72)^{* *}$ \\
\hline Employee referral & 0.665 & $(2.91)^{* *}$ & 0.919 & $(4.21)^{* *}$ \\
\hline Education: R. obtained A-levels & 0.068 & $(0.29)$ & 0.171 & $(0.79)$ \\
\hline Training: at least 1 year outside school & -0.272 & $(1.11)$ & 0.127 & $(0.62)$ \\
\hline Gender: male & 0.381 & $(1.72)$ & 0.102 & $(0.50)$ \\
\hline Region: Budapest or western part & 0.780 & $(3.43)^{* * *}$ & 0.453 & $(2.16) *$ \\
\hline Constant & -2.081 & $(6.23)^{* * *}$ & -1.842 & $(6.59)^{* *}$ \\
\hline $\mathrm{N}$ of observations ( $\mathrm{N}$ of clusters) & 559 & (279) & 576 & $(281)$ \\
\hline$\%$ reduction in log likelihood & 0.056 & & 0.052 & \\
\hline$\chi^{2}$ statistics $(\mathrm{df}=6)$ & $28.83^{* * *}$ & & $36.46^{* * *}$ & \\
\hline
\end{tabular}

Notes: Raw (or unstandardized) parameter estimates; figures in parentheses are absolute values of $\mathrm{t}$ ratios. Standard errors are adjusted for clustering on classes within schools.

$* \mathrm{p}<0.05 ; * * \mathrm{p}<0.01 ; * * * \mathrm{p}<0.001$; two-tailed tests

Given the theory of employee referrals and social resources theory, we expect the coefficients of these two dummies to be positive. All coefficients of contact variables are positive and statistically significant. These findings support both the theory of employee referrals and social resources theory. The coefficients of employee referrals are slightly larger and they have larger $t$ ratios as well. The control variables exhibit patterns similar to the results in Table 3. People living in the western part of Hungary are more likely to find good jobs. It is striking that education and gender do not seem to affect the chances of finding a "good" job.

Finally, we examine the effects of job-finding methods and contact characteristics on earnings opportunities. Table 5 presents estimates of four multiple linear regression models of earnings opportunities. Models [1] and [2] show the effect of informal search compared to the formal and direct channels. Since job-finding methods are identified by formal and direct channels - informal channel is the omitted category -, we expect that the formal and direct search dummies will have negative coefficients. Models [3] and [4] replace the formal and direct search dummies by the variables expressing contact characteristics. Contact characteristics are dummies coded in a way that they take the value zero when one finds a job through formal and direct channels, as well. Thus, these dummies compare the effectiveness of finding a job through high-status contacts and through employee referrals to all other ways of finding a job. Models [1] and [3] use the same independent variables as the models presented earlier (see Tables 3 and 4). Models [2] and [4] also control for job characteristics. Remember that we found a positive relationship between contacts and job characteristics in the previous section. Since firm size and foreign property are expected to have a positive effect on wages, contact characteristics should have an indirect effect on earnings opportunities. Thus, while models [1] and [3] estimate "total" returns to contacts, models [2] and [4] estimate "net" returns by controlling for the possible indirect contact effects on earnings. This means, if job-finding methods or contact characteristics have an effect in models [2] and [4], we have evidence to conclude that job-finding methods or contact characteristics lead to good jobs not only because they 
help people to find a job in firms where average salaries are high, but also because they help to find a good job or to secure a good salary within any kind of firm.

Table 5. OLS regressions of log earnings associated with job opportunities

\begin{tabular}{|c|c|c|c|c|}
\hline Variables & Model [1] & Model [2] & Model [3] & Model [4] \\
\hline Employment service & $\begin{array}{r}-0.098 \\
(1.92)\end{array}$ & $\begin{array}{r}-0.067 \\
(1.28)\end{array}$ & & \\
\hline Advertisement & $\begin{array}{r}0.001 \\
(0.04)\end{array}$ & $\begin{array}{r}-0.021 \\
(0.61)\end{array}$ & & \\
\hline Direct methods & $\begin{array}{c}-0.083 \\
(2.38)^{*}\end{array}$ & $\begin{array}{r}-0.050 \\
(1.47)\end{array}$ & & \\
\hline High-status contact & & & $\begin{array}{r}0.140 \\
(3.21)^{* *}\end{array}$ & $\begin{array}{r}0.123 \\
(2.87)^{* *}\end{array}$ \\
\hline Employee referral & & & $\begin{array}{c}0.012 \\
(0.38)\end{array}$ & $\begin{array}{r}-0.013 \\
(0.41)\end{array}$ \\
\hline Foreign property in firm & & $\begin{array}{r}0.193 \\
(5.53)^{* * *}\end{array}$ & & $\begin{array}{r}0.201 \\
(6.00)^{* * *}\end{array}$ \\
\hline Large firm: $\mathrm{N}$ of employees $>50$ & & $\begin{array}{c}0.004 \\
(0.10)\end{array}$ & & $\begin{array}{r}-0.007 \\
(0.12)\end{array}$ \\
\hline White-collar job & & $\begin{array}{r}0.091 \\
(3.22)^{* *}\end{array}$ & & $\begin{array}{r}0.088 \\
(3.09)^{* *}\end{array}$ \\
\hline Education: R. obtained A-levels & $\begin{array}{r}0.067 \\
(2.30)^{*}\end{array}$ & $\begin{array}{r}0.044 \\
(1.56)\end{array}$ & $\begin{array}{r}0.074 \\
(2.51)^{*}\end{array}$ & $\begin{array}{r}0.048 \\
(1.67)\end{array}$ \\
\hline Training: at least 1 year outside school & $\begin{array}{r}-0.038 \\
(1.26)\end{array}$ & $\begin{array}{r}-0.021 \\
(0.74)\end{array}$ & $\begin{array}{r}-0.047 \\
(1.56)\end{array}$ & $\begin{array}{r}-0.029 \\
(1.02)\end{array}$ \\
\hline Gender: male & $\begin{array}{r}0.117 \\
(4.27)^{* * *}\end{array}$ & $\begin{array}{r}0.110 \\
(4.10)^{* * *}\end{array}$ & $\begin{array}{r}0.115 \\
(4.00)^{* * *}\end{array}$ & $\begin{array}{r}0.110 \\
(4.02)^{* * *}\end{array}$ \\
\hline Region: Budapest or western part & $\begin{array}{r}0.235 \\
(8.77)^{* * *}\end{array}$ & $\begin{array}{r}0.204 \\
(7.60)^{* * *}\end{array}$ & $\begin{array}{r}0.240 \\
(8.45)^{* * *}\end{array}$ & $\begin{array}{r}0.210 \\
(7.47)^{* * *}\end{array}$ \\
\hline Constant & $\begin{array}{r}3.071 \\
(98.92)^{* * *}\end{array}$ & $\begin{array}{r}3.019 \\
(94.98)^{* * *}\end{array}$ & $\begin{array}{r}3.024 \\
(90.16)^{* * *}\end{array}$ & $\begin{array}{r}2.988 \\
(89.08)^{* * *}\end{array}$ \\
\hline $\mathrm{N}$ of observations & 536 & 514 & 521 & 500 \\
\hline $\mathrm{N}$ of clusters & 275 & 269 & 273 & 267 \\
\hline Model degrees of freedom & 7 & 10 & 6 & 9 \\
\hline Residual degrees of freedom & 274 & 268 & 272 & 266 \\
\hline R squared & 0.189 & 0.261 & 0.195 & 0.274 \\
\hline F statistic & $16.01 * * *$ & $18.67 * * *$ & $19.30 * * *$ & $22.67 * * *$ \\
\hline
\end{tabular}

Notes: Raw (or unstandardized) parameter estimates; figures in parentheses are absolute values of t ratios. Standard errors are adjusted for clustering on classes within schools.

$* \mathrm{p}<0.05 ; * * \mathrm{p}<0.01 ; * * * \mathrm{p}<0.001 ;$ two-tailed tests

First, we examine the effect of job-finding methods (models [1] and [2]). Since the regressions are run on the natural log of earnings, coefficients indicate percentage changes in earnings. For example, the coefficient associated with using the employment service is -0.098 . This implies that people who found the job through this channel earn less than people who found a job through contacts by around 9.3 percent $\left(\mathrm{e}^{-0.098}=0.907\right)$. In the first column, two job-finding methods, contacting the employer or the firm directly and employment service, have negative coefficients. However, only the coefficient of direct search is significant at the 5 percent level. Note that the $t$

Review of Sociology 9 (2003) 
ratio of employment service variable is relatively large $(t=1.925, p=0.055)$. The coefficient of advertisement is virtually zero, implying that advertisements lead to as good jobs as personal contacts. Thus, there is some evidence that informal methods lead to better jobs in terms of earnings than employment services and direct methods. Moving to model [2], direct methods and employment services become smaller and statistically insignificant. This implies that a part of the effect of informal job-finding methods is mediated by job characteristics. Remember that direct methods and employment services are less likely to lead to jobs in foreign property (consult Table 3). Thus, job-finding methods do not affect starting earnings within firms and job categories.

Models [3] and [4] compare the effects of good contacts (high-status contact, employee referral) to other job-finding methods. There is only one contact variable which has the expected positive effect on earnings: contact status. In model [3], the estimated earnings advantage associated with high status contacts is about 15 percent $\left(\mathrm{e}^{0.14}=1.150\right)$. Moving to model [4], we see that this earnings advantage gets somewhat smaller: taking job characteristics into account, high-status contacts inform about jobs where earnings are higher by 13 percent $\left(\mathrm{e}^{0.123}=1.131\right)$. Job characteristics take away only a small fraction of the earnings advantage. Additionally, the earnings advantage remains statistically significant at 5 percent level.

This behavior of contact status effects is similar to the behavior of the ascriptive characteristics, like gender. Gender (and also regional) effects are independent of job characteristics. Contrary to this, the inclusion of job characteristics substantially reduces the effect of education, a variable expressing individual achievement. Analyses not reported here showed that white-collar jobs are associated with larger earnings and access to white-collar jobs depends on education. Thus, a substantial part of the effect of education on earnings is mediated by the type of job one has found.

\section{Getting the Job}

This section examines whether contact characteristics have any impact on the chances of getting the job. Note that the vast majority of people who have found a job also got the job: the probability of getting the offer is about 80 percent (see Table 1). Therefore, even if we find contact effects, it is likely that their practical significance is low.

Table 6 shows the distribution of the chances of getting the job one has found across job-finding methods (panel A) and contact characteristics (panel B). At first sight, there is some evidence about the effects of job-finding methods, but no evidence for contact characteristics effects. The probability of getting the job offer ranges between 77 and 93 percent across the categories of job-finding methods. The differences in proportions across the categories of job-finding methods are statistically significant. Therefore, we can conclude that job-finding methods affect the chances of finding a job, and these chances are the highest for those who found the job opportunity through direct methods. Given the evidence, we cannot conclude that informal methods are the best way to get the job opportunity or these chances are affected by the characteristics of the contact person. 
Table 6. The probabilities of getting a job by source of job information and contact characteristics (in percentage form)

\begin{tabular}{|c|c|c|c|}
\hline \multicolumn{2}{|l|}{$\begin{array}{l}\text { Panel } \boldsymbol{A} \\
\text { Source of job information }\end{array}$} & \multicolumn{2}{|l|}{$\begin{array}{l}\text { Panel } \boldsymbol{B} \\
\text { Characteristics of contact person }\end{array}$} \\
\hline Employment service & 76.9 & Low status, not employee & 81.4 \\
\hline Advertisement & 77.6 & High status, not employee & 79.4 \\
\hline Direct methods & 92.8 & Low status employee & 87.6 \\
\hline Contact person & 83.9 & High-status employee & 79.4 \\
\hline $\begin{array}{l}\text { Pearson } \chi^{2} \text { test of independence } \\
(\mathrm{df}=3)\end{array}$ & 13.29 & $\begin{array}{l}\text { Pearson } \chi^{2} \text { test of independence } \\
(\mathrm{df}=3)\end{array}$ & 2.33 \\
\hline p-value & 0.004 & p-value & 0.075 \\
\hline
\end{tabular}

This conclusion was further supported by multiple logistic regression analyses. I estimated two models: the first model included job-finding methods, while the second model the contact characteristics. The results of the first model, not displayed here, showed that finding a job through advertisement has a negative, while finding a job through direct methods has a positive effect on getting the job. Therefore, informal methods are more helpful than advertisements, but less helpful than direct methods to get the job one has found. Results from the second model showed that the effect of informal channels is independent of contact characteristics. The parameter estimates of contact status and employee referral variables are not significant.

These findings suggest that getting the job depends only on using direct methods. This finding is interesting. Earlier we have found (see Tables 2-5) that people using direct methods find bad job opportunities. Taken together, direct methods create incentives to take a relatively bad job. Although high-status contacts and employee referrals help people to find a good opportunity, these contact characteristics do not help one to get this job. Thus, we should empirically examine the question whether the use of high-status contacts or employee referrals lead to good jobs.

\section{Having a Good Job}

In the previous two sections, two processes were examined: finding a good job opportunity and getting that job. This section examines how these two processes add up. The method consists of replicating the analyses reported in Section 4.1 using the sample of employees. First, I replicated the analyses of firm and job characteristics. The results from the replications were similar to the findings described in Section 4.1 and they led to the same qualitative conclusions. Therefore, these analyses are not reported here.

The analyses reported here focus on extending the analyses of starting earnings. It was found in Section 4.1 that high-status contacts lead to job opportunities with higher salaries even if we control for firm characteristics and the type of occupation. The interpretation for this finding was that high-status contacts lead to jobs with higher salaries within firms and job categories. A generalization of this interpretation is that contact status affects earnings independently of job characteristics. Using the sample of employees, it is possible to test a specific version of this generalization. The school 
leaver survey contains several items about the characteristics of the employment relationship, which cannot be observed among job seekers before they take the job. If it is true that high-status contacts affect earnings independently of job characteristics, then entering variables reflecting the characteristics of employment relationship should not affect the coefficient of high-status contact.

The characteristics of the employment relationship are captured by four variables. The first is the natural log of average weekly working time. The second variable is a dummy identifying bad working conditions. This variable is used to account for compensating wage differentials (Rosen 1986). Those who work in jobs with bad working conditions are expected to earn more than those who did not work in such jobs. Finally, various efficiency wage theories, which provide the foundations for the theory of employee referrals, argue that monitoring problems are solved by paying a wage premium. Based on this argument, supervision and the system of payment are used as indicators for monitoring problems. The supervision variable is a dummy identifying those who are supervised once a month or more rarely. Thus, it expresses the looseness of the absence of supervision. The system of payment dummy identifies those whose salary depends on individual performance.

Table 7 presents estimates for two linear regression models. In both models, log earnings are regressed on contact characteristics using the sample of employees. Model [1] includes the same variables as model [4] of Table 5. Model [2] extends the analysis by adding working time, working conditions, supervision, and system of payment to the first model.

Table 7. OLS regressions of log starting earnings among employees

\begin{tabular}{|c|c|c|c|c|}
\hline \multirow[b]{2}{*}{ High status contact } & \multicolumn{2}{|l|}{ Model [1] } & \multicolumn{2}{|c|}{ Model [2] } \\
\hline & 0.139 & $(3.06)^{* *}$ & 0.127 & $(2.93)^{* *}$ \\
\hline Employee referral & -0.021 & $(0.69)$ & -0.024 & $(0.78)$ \\
\hline Natural log of working time & & & 0.291 & $(3.39)^{* * *}$ \\
\hline Working conditions are bad & & & 0.062 & $(2.30)^{*}$ \\
\hline Supervision: once a month or less often & & & 0.094 & $(3.11)^{* *}$ \\
\hline System of payment: depends on performance & & & 0.043 & $(1.24)$ \\
\hline Foreign property in firm & 0.212 & $(6.42)^{* * *}$ & 0.209 & $(6.46)^{* * *}$ \\
\hline Large firm: $\mathrm{N}$ of employees $>50$ & -0.022 & $(0.77)$ & -0.008 & $(0.25)$ \\
\hline White-collar job & 0.082 & $(2.92)^{* *}$ & 0.095 & $(3.48)^{* * *}$ \\
\hline Education: R. obtained A-levels & 0.055 & $(1.88)$ & 0.060 & $(2.16)^{*}$ \\
\hline Gender: male & 0.112 & $(4.11)^{* * *}$ & 0.092 & $(3.37)^{* * *}$ \\
\hline Region: Budapest or western part & 0.202 & $(7.30)^{* * *}$ & 0.206 & $(7.54)^{* * *}$ \\
\hline Constant & 2.982 & $(103.5)^{* * *}$ & 1.844 & $(5.71)^{* * *}$ \\
\hline $\mathrm{N}$ of observations ( $\mathrm{N}$ of clusters) & 437 & $(251)$ & 430 & $(251)$ \\
\hline Model degrees of freedom & 8 & & 12 & \\
\hline Residual degrees of freedom & 250 & & 250 & \\
\hline R squared & 0.298 & & 0.36 & \\
\hline F statistic & $26.75 * * *$ & & $21.47 * * *$ & \\
\hline
\end{tabular}

Notes: Raw (or unstandardized) parameter estimates; figures in parentheses are absolute values of $\mathrm{t}$ ratios. Standard errors are adjusted for clustering on classes within schools.

${ }^{*} \mathrm{p}<0.05 ; * * \mathrm{p}<0.01 ;{ }^{* * *} \mathrm{p}<0.001$; two-tailed tests 
The comparison of Model [1] to Model [2] shows that the coefficients of contact characteristics remain relatively stable. The inclusion of employment relationship variables takes away only 10 percent of the earnings advantage associated with high status contacts $\left(\mathrm{e}^{0.139}-1=0.149 ; \mathrm{e}^{0.127}-1=0.135\right)$. Additionally, the coefficient of contact status remains statistically significant. In short, the earnings advantage associated with using high status contacts is independent of other determinants of earnings, such as working time, compensating differentials, and monitoring problems. Therefore, high-status contacts lead to jobs with higher earnings within firm and job categories.

\section{CONCLUSIONS}

This paper examines whether friends and relatives help job seekers to get a good job in Hungary. More specifically, our aim was to answer two research questions. The first question is whether job searchers are more likely to find good jobs with the help of informal intermediaries than through other job-finding methods. Since previous research on contact effects has shown that the use of informal search in itself rarely leads to good jobs, we identified two theories that can account for the conditions under which personal contacts help job searchers to get good jobs (see Section 2). Social resources theory, a follow-up to the famous strength of weak ties hypothesis, argues that returns to informal methods depend on the status of the contact person. The theory of employee referrals argues that good jobs can be accessed with the help of employee referrals. Thus, we ask a second research question: is it true that informal job search leads to good job only if the contact person is either a high-status person or an employee where the job opening is?

The research questions were examined using a rather unique dataset on young people who have completed their secondary vocational education in 1998 and tried to find a job during 1998 and 1999. The main findings are as follows. On the one hand, there is no evidence that informal contacts in themselves always lead to good jobs. On the other hand, we found evidence for the hypothesis that getting a good job depends on the characteristics of the contact person. Both high status contacts and employee referrals are helpful to find job in a firm with attractive characteristics. Additionally, high-status contacts have a direct effect on the earnings associated with the job. Since earnings are positively correlated with one of the firm characteristics under study, good contacts have an indirect effect on earnings as well. However, there is no evidence indicating that contact characteristics would have an impact on the probability of getting the job opportunity. Here one should keep in mind that the vast majority of people who have found a job also got the job. As a consequence, good contacts are likely to lead to good jobs because good contacts generate better opportunities than other sources. These findings clearly support social resources theory and the theory of employee referrals.

The research reported in this paper can be viewed as a contribution towards answering a more general question: how networks contribute to inequalities and what are the mechanisms and institutions that generate these network effects. Thus, our study can be seen as a contribution to the social capital research program (Flap 1999).

Review of Sociology 9 (2003) 
Our empirical findings have two important implications for researchers who wish to contribute to this research program. First, as the idea of social capital gains popularity among social scientists, there is a tendency to describe the total effect of social networks on labor market outcomes and to explain the empirical findings using the assumption that networks are capital that bring returns. This procedure is flawed because networks should not be described as capital when it is not shown which processes generate these returns (Baron and Hannan 1994). Our empirical analyses assume that network resources have no direct causal effect on labor-market outcomes. Rather, network resources are assumed to have an effect on the use of informal job-finding methods and the characteristics of the contact person. Since the results reported in this paper show that contact characteristics have an impact on the chances of finding a good job, a social capital effect exists only if there is a positive relationship between network resources and contact characteristics. Analyses not reported here failed to support the latter relationship, thus it would be premature to claim that personal contacts constitute a social capital in the context of job search. Second, our analyses opened the black box of contact effects: we have shown that high status contacts and referrals lead to good jobs because they generate good job offers. This finding contributes to a detailed description of the processes that generate social capital or contact effects.

\section{REFERENCES}

Akerlof, G.A. (1982): Labor Contracts as Partial Gift Exchange. Quarterly Journal of Economics, 97: 543-569.

Arthur, W.B. (1988): Self-Reinforcing Mechanisms in Economics. In Anderson, P.W. et al. (eds): The Economy as an Evolving Complex System. Reading, MA.: Addison-Wesley, 9-31.

Baron, J.N. and Hannan, M.T. (1994): The Impact of Economics on Contemporary Sociology. Journal of Economic Literature, 32: 1111-1146.

Bartus, T. (2001): Social Capital and Earnings Inequalities. The Role of Informal Job Search in Hungary. Manuscript.

Beggs, J.L. and Hurlbert, J.S. (1997): The Social Context of Men's and Women's Job Search Ties: Membership in Voluntary Organizations, Social Resources, and Job Search Outcornes. Sociological Perspectives, 40: 601-622.

Bian, Y. (1997): Bringing Strong Ties Back. In: Indirect Ties, Network Bridges, and Job Searches in China. American Sociological Review 62: 366-385.

Bian, Y. and Ang, S. (1997): Guanxi Networks and Job Mobility in China and Singapore. Social Forces 75: 981-1006.

Boxman, E.A.W. (1992): Contacten en Carriere. Een Empirisch-Theoretisch Onderzoek naar de Relatie tussen Sociale Netwerken en Arbeidsmarktposities. [Contacts and Careers: A Study of Social Networks and Labor Market Outcomes] Amsterdam: Thesis Publisher.

Boxman, E.A.W., Flap, H.D. and de Graaf, P.M. (1991): The Influence of Social and Human Capital on the Income of Dutch Managers. Social Networks 13: 51-73.

Böröcz, J. and Southworth, C. (1998): 'Who You Know' Earnings Effects of Formal and Informal Social Network Resources under Late State Socialism in Hungary, 1986-1987. Journal of Socio-Economics, 27: 401-425. 
Bridges, W.P. and Villemez, W.J. (1986): Informal Hiring and the Labor Market. American Sociological Review, 51: 574-582.

Campbell, K.E., Marsden, P. V. and Hurlbert, J. S. (1986): Social Resources and Socioeconomic Status. Social Networks 8: 97-117.

Csegény, P., Kákai, L., Madár, Cs. and Szabó, A. (1996): Felsőoktatás és munkaerőpiac. [Higher Education and Labor Market] Társadalmi Szemle 51 (8-9): 98-110.

Czakó, Á. and Sík, E. (1994): Hálózati tőke a posztkommunista Magyarországon. [Network Capital in Post-communist Hungary] Mozgó Világ 6: 17-25.

Czakó, Á. and Sík, E. (1995): A hálózati tőke szerepe Magyarországon a rendszerváltás előtt és után. [The Role of Network Capital in Hungary before and after the Transition ] 2000 (2): $3-17$.

David, P. (1985): Clio and the Economics of QWERTY. American Economic Review 75: 332-337.

de Graaf, N.D. and Flap, H. (1988): With a Little Help from My Friends. Social Forces, 68 453-472.

Decker, P.J. and Cornelius, E.T. (1979): A Note on Recruiting Sources and Job Survival Rates. Journal of Applied Psychology, 64: 463-464.

Ensel, W.M. (1979): Sex, Social Ties, and Status Attainment. Unpublished PhD dissertation. State University of New York, Albany.

Ericksen, E. and Yancey, W. (1980): Class, Sector and Income Determination. Unpublished manuscript, Temple University. [Cited in Granovetter (1982).]

Fazekas, K. and Köllö, J. (1999): A külföldi érdekeltségű vállalatok munkaerö-keresletének jellemzői Magyarországon, 1995-ben. [Labor Demand of Foreign Firms in Hungary in 1995] In Fazekas, K. et. al. (eds.): Relokáció: A munkahelyek áttelepülése Nyugat-Európából Magyarországra. Budapest: Miniszterelnöki Hivatal, Integrációs Stratégiai Munkacsoport, 39-88.

Fernandez, R.M., Castilla, E. and Moore, P. (2000): Social Capital at Work: Networks and Hiring at a Phone Center. American Journal of Sociology, 105: 1288-1356.

Fischer, C.S. (1982): To Dwell among Friends: Personal Networks in Town and City. Chicago: University of Chicago Press.

Flap, H. (1999): Creation and Returns of Social Capital. A New Research Program. The Tocqueville Review 20: 1-22.

Flap, H.D., and de Graaf, N. D. (1986): Social Capital and Attained Occupational Status. The Netherlands Journal of Sociology 22: 145-161.

Flap, H.D., and Tazelaar, F. (1989): The Role of Informal Social Networks on the Labor Market: Flexibilization and Closure. In Flap, H. (ed.): Flexibilization of the Labor Market. Utrecht: ISOR, University of Utrecht, 99-118.

Gábor, R.I. (1997): Belső versus foglalkozási munkaerőpiac - a posztszocialista átalakulás elhanyagolt dimenziója. [Internal Versus Occupational Labor Market: A Neglected Aspect of Post-socialist Transformation] Közgazdasági Szemle, 44: 457-473.

Gábor, R.I. (1999): Post-Socialist Transformation and the Labour Market in Hungary: The Quest of Institutional Realignment. Acta Oeconomica, 50: 103-117.

Granovetter, M. (1973): The Strength of Weak Ties. American Journal of Sociology, 78: $1360-1380$.

Granovetter, M. (1974): Getting a Job: A Study of Contacts and Careers. Cambridge, MA: Harvard University Press.

Granovetter, M. (1995): Afterword, 1994: Reconsiderations and a New Agenda. In Granovetter, M.: Getting a Job: A Study of Contacts and Careers. Second Edition. Chicago: University of Chicago Press, 139-182.

Review of Sociology 9 (2003) 
Greenwell, L., Valdez, R.B. and DaVanzo, J. (1997): Social Ties, Wages, and Gender in a Study of Salvadorean and Pilipino Immigrants in Los Angeles. Social Science Quarterly, 78: 559-577.

Holzer, H.J. (1987): Hiring Procedures in the Firm: Their Economic Determinants and Outcomes. NBER Working Paper 2185.

Kertesi, G. and Köllő, J. (1997): Reálbérek és kereseti egyenlőtlenségek, 1986-1996, I. rész [Real Wages and Earnings Inequalities, 1986-1996, part I.]. Közgazdasági Szemle, 44: 612-634.

Kertesi, G. and Köllő, J. (1998): Reálbérek és kereseti egyenlőtlenségek, 1986-1996, II. rész [Real Wages and Earnings Inequalities, 1986-1996, part II.]. Közgazdasági Szemle, 45: $621-652$

Kugler, A.D. (1997): Employee Referrals and the Inter-Industry Wage Structure. Universitat Pompeu Fabra, Dept. of Economics, Economics Working Paper 252.

Lai, G., Lin, N. and Leung, S. (1998): Network Resources, Contact Resources, and Status Attainment. Social Networks, 20: 159-178.

Laki, L. [unpublished]: Falusi fiatalok helyzete. [Survey of Youth Living in Villages] Unpublished research findings.

Laki, M. (1997): Kisvállalkozások a szocializmus után. [Small Enterprises after Socialism] Budapest: MTA Közgazdaságtudományi Kutatóintézet, Unpublished paper.

Laumann, E.O. (1966): Prestige and Association in an Urban Community: An Analysis of an Urban Stratification System. Indianapolis: Bobbs-Merrill.

Lin, N. (1982): Social Resources and Instrumental Action. In Marsden, P.V. and Lin, N. (eds.): Social Structure and Network Analysis. Beverly Hills: Sage, 131-145.

Lin, N. (1990): Social Resources and Social Mobility: A Structural Theory of Status Attainment. In Breiger, R.L. (ed.): Social Mobility and Social Structure. Cambridge: Cambridge University Press, 247-271.

Lin, N. (1999): Social Networks and Status Attainment. Annual Review of Sociology, 25: 467-487.

Lin, N., Dayton, P. and Greenwald, P. (1978): Analyzing the Instrumental Use of Relations in the Context of Social Structure. Sociological Methods and Research, 7: 149-166.

Lin, N., Vaughn, W.N. and Ensel, J.C. (1981): Social Resources and Strength of Ties. American Sociological Review, 46: 393-405.

Manwaring, T. (1984): The Extended Internal Labour Market. Cambridge Journal of Economics, 8: 161-187.

Manwaring, T. and Wood, S. (1984): Recruitment and the Recession. International Journal of Social Economics, 11: 49-63.

Marsden, P.V. (1988): Homogeneity in Confiding Relations. Social Networks, 10: 57-76.

Marsden, P.V. and Campbell, K.E. (1990): Recruitment and Selection Processes: The Organizational Side of Job Searches. In Breiger, R.L. (ed.): Social Mobility and Social Structure. Cambridge: University Press, 59-79.

Marsden, P.V. and Gorman, E.H. (2001): Social Networks, Job Changes, and Recruitment. In Berg, I. and Kalleberg, A. (eds.): Sourcebook on Labor Markets: Evolving Structures and Processes. New York: Kluwer Academic/Plenum, 467-502.

Marsden, P.V. and Hurlbert, J.S. (1988): Social Resources and Mobility Outcomes: A Replication and Extension. Social Forces, 66: 1038-1059.

Mencken, F.C. and Winfield, I. (1998): In Search of the 'Right Stuff': The Advantages and Disadvantages of Informal and Formal Recruiting Practices in External Labor Markets. American Journal of Economics and Sociology, 57: 135-153. 
Montgomery, J.D. (1991): Social Networks and Labor Market Outcomes: Toward an Economic Analysis. American Economic Review, 81: 1408-1418.

Neckerman, K.M. and Kirschenman, J. (1991): Hiring Strategies, Racial Bias, and Inner-City Workers. Social Problems, 38: 433-447.

North, D. (1990): Institutions, Institutional Change and Economic Performance. Cambridge: University Press

Preisendörfer, P. and Voss, T. (1988): Arbeitsmarkt und soziale Netzwerke: Die Bedeutung sozialer Kontakte beim Zugang zu Arbeitsplatzen. Soziale Welt, 39: 104-119.

Rees, A. (1966): Information Networks in Labor Markets. American Economic Review, 66: 559-566.

Rees, A. and Shultz, T. (1970): Workers and Wages in an Urban Labor Market. Chicago: University of Chicago Press.

Requena, F. (1991): Social Resources and Occupational Status Attainment in Spain: A Cross-National Comparison with the United States and The Netherlands. International Journal of Comparative Sociology, 32: 233-242.

Shapiro, C. and Stiglitz, J.E. (1984): Equilibrium Unemployment as a Worker Discipline Device. American Economic Review, 74: 433-444.

Sík, E. (1994): Network Capital in Capitalist, Communist, and Post-Communist Societies. International Contributions to Labor Studies, 4: 79-93.

Ullman, J.C. (1968): Interfirm Differences in the Cost of Search for Clerical Workers. Journal of Business, 41: 153-165.

Verbrugge, L. (1977): The Structure of Adult Friendship Choices. Social Forces, 56: 576-597.

Völker, B. and Flap, H. (1999): Getting Ahead in the GDR: Social Capital and Status Attainment Under Communism. Acta Sociologica, 42: 17-34.

Wanous, J.P. (1980): Organizational Entry: Recruitment, Selection, and Socialization of Newcomers. Reading (Mass.): Addison-Wesley.

Wegener, B. (1991): Job Mobility and Social Ties: Social Resources, Prior Job, and Status Attainment. American Sociological Review, 56: 60-71.

Wial, H. (1991): Getting a Good Job: Mobility in a Segmented Labor Market. Industrial Relations, 30: 396-416.

Williams, C.R., Labig, C.E. and Stone, T.H. (1993): Recruitment Sources and Posthire Outcomes for Job Applicants and New Hires: A Test of Two Hypotheses. Journal of Applied Psychology, 78: 163-172.

Yellen, J. L. (1986): Efficiency Wage Models of Unemployment. American Economic Review, 74: 200-205. 